\title{
ABL-N-induced apoptosis in human breast cancer cells is partially mediated by c-Jun $\mathrm{NH}_{2}$-terminal kinase activation
}

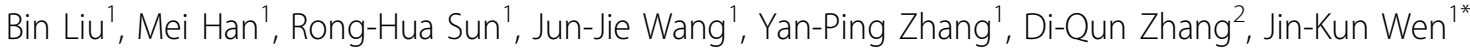

\begin{abstract}
Introduction: The present study was designed to determine the possibility of acetylbritannilactone (ABL) derivative 5-(5-(ethylperoxy)pentan-2-yl)-6-methyl-3-methylene-2-oxo-2,3,3a,4,7,7a-hexahydrobenzofuran-4-yl 2-(6methoxynaphthalen-2-yl)propanoate (ABL-N) as a novel therapeutic agent in human breast cancers.

Methods: We investigated the effects of ABL-N on the induction of apoptosis in human breast cancer cells and further examined the underlying mechanisms. Moreover, tumor growth inhibition of ABL-N was done in xenograft models.

Results: ABL-N induced the activation of caspase-3 in estrogen receptor (ER)-negative cell lines MDA-MB-231 and MDA-MB-468, as evidenced by the cleavage of endogenous substrate Poly (ADP-ribose) polymerase (PARP). Pretreatment of cells with pan-caspase inhibitor z-VAD-fmk or caspase-3-specific inhibitor z-DEVD-fmk inhibited ABL-N-induced apoptosis. ABL-N treatment also resulted in an increase in the expression of pro-apoptotic members (Bax and Bad) with a concomitant decrease in Bcl-2. Furthermore, c-Jun- $\mathrm{NH}_{2}$-terminal kinase (JNK) and p38 mitogen-activated protein (MAP) kinase (p38) were activated in the apoptosis induced by ABL-N and JNK-specific inhibitor SP600125 and JNK small interfering RNA (siRNA) antagonized ABL-N-mediated apoptosis. However, the p38-specific inhibitor SB203580 had no effect upon these processes. Moreover, neither of the caspase inhibitors prevented ABL-N-induced JNK activation, indicating that JNK is upstream of caspases in ABL-N-initiated apoptosis. Additionally, in a nude mice xenograft experiment, ABL-N significantly inhibited the tumor growth of MDA-MB-231 cells.
\end{abstract}

Conclusions: ABL-N induces apoptosis in breast cancer cells through the activation of caspases and JNK signaling pathways. Moreover, ABL-N treatment causes a significant inhibition of tumor growth in vivo. Therefore, it is thought that ABL-N might be a potential drug for use in breast cancer prevention and intervention.

\section{Introduction}

Breast cancer is one of the most common cancers among women in both developed and underdeveloped countries. It is the malignancy with the highest incidence and death rate for women [1,2]. However, the efficacy of the present drugs is very limited, and it is urgent to find the anticancer compounds that can target multiple points in the apoptotic cascade to achieve synergistic actions. Chinese herbs have obtained considerable attention for the prevention and treatment of certain cancer types in clinical

\footnotetext{
* Correspondence: wjk@hebmu.edu.cn

'Department of Biochemistry and Molecular Biology, Institute of Basic Medicine, Hebei Medical University, No.361, Zhongshan East Road, Shijiazhuang, 050017, China

studies [3-6]. In many cases, the extracts obtained from the plants are not highly effective and require chemical modification for improved potency and toxicity profile [7-9]. Thus, studies of naturally plant-based agents could supply new strategies for the management of cancer and related diseases $[7,10,11]$.

Recently, several phytochemicals that have been used in clinical cancer chemotherapy were derived from herbs and plants, such as paclitaxel [5,12], etoposide [13], camptothecin [4] and vinca alkaloids [14]. Acetylbritannilactone (ABL) is a sesquiterpene lactone abundant in Inula britannica $L$, which is used to treat bronchitis and inflammation. In the previous work, it is demonstrated that $\mathrm{ABL}$ inhibits the expression of 
inflammation-associated genes and it possesses anticancer properties [15-19]. In the course of our continuing search for cytotoxic ABL analogues, we synthesized the compound 5-(5-(ethylperoxy)pentan-2-yl)-6-methyl-3methylene-2-oxo-2,3,3a,4,7,7a-hexahydrobenzofuran-4-yl 2-(6-methoxynaphthalen-2-yl)propanoate (ABL-N), which in preliminary studies showed exceptional antiproliferative activity against several human cancer cell types. Here, we showed that ABL-N was more potent than ABL in the ability to induce apoptosis, at a low concentration, of human breast cancer cells and investigated the therapeutic potential of the ABL-N and its underlying mechanism of action.

\section{Materials and methods}

\section{Preparation of $A B L$ and $A B L-N$}

Silica gel column chromatography was used to isolate ABL from Inula britannica $L$ grown in Shan-xi Province in China. ABL-N was synthesized to improve efficacy and pharmacologic characteristics by substitution at C-6 of ABL (Figure 1a). These compounds were characterized by nuclear magnetic resonance and mass spectroscopy. The purified ABL and ABL-N were dissolved in ethanol at 1,000-fold final concentration and added to cells in exponential growth. The effects of ABL and ABL-N on our experiments were compared with the same concentration of ethanol as vehicle.

\section{Reagents}

3-(4,5-dimethylthiazol-2-yl)-2,5-diphenyltetrazoliumbromide (MTT), DMSO, 4,6-diamidino-2-phenylindole (DAPI), small interfering RNA (siRNA) specific for human JNK mRNA and control siRNA were obtained from Sigma Chemicals (St. Louis, MO, USA). LipofectAMINE 2000, Dulbecco's modified Eagle's medium (DMEM), penicillin, and streptomycin were purchased from Invitrogen (Carlsbad, CA, USA). The antibodies specific for Poly (ADPribose) polymerase (PARP), c-Jun $\mathrm{NH}_{2}$-terminal kinase (JNK), phospho-JNK, p38 MAP kinase (p38) and phospho-p38 were obtained from Cell Signaling Technology (Beverly, MA, USA). Antibodies against extracellular signal-regulated kinase (ERK), phospho-ERK, caspase-3, caspase-9, c-Jun, phospho-c-Jun, Bcl-2, Bax, Bad and secondary antibodies were from Santa Cruz Biotechnology (Santa Cruz, CA, USA). Pan-caspase inhibitor (z-VADfmk) was from Promega (Madison, WI, USA) and caspase-3-specific inhibitor (z-DEVD-fmk) was obtained from CalBiochem (San Diego, CA, USA). Unless otherwise indicated, all other reagents used in this study were obtained from Sigma Chemicals.

\section{Cell lines and culture conditions}

The human breast cancer cell lines (MCF-7, MDA-MB468 and MDA-MB-231), the human prostate carcinoma cells (Du145 and PC-3), and the human colon carcinoma cells (LoVo and HT-29) were from the American Type Culture Collection. Normal human breast epithelial cells (NBECs) were cultured and characterized as described previously from reduction mammoplasty specimens [20,21]. Cells were grown in a $5 \% \mathrm{CO}_{2}$ atmosphere at $37^{\circ} \mathrm{C}$ in DMEM supplemented with 100 units/ $\mathrm{ml}$ penicillin, $100 \mu \mathrm{g} / \mathrm{ml}$ streptomycin, $1 \%$ nonessential amino acids, and $10 \%$ fetal bovine serum (v/v). All treatments were carried out on cells at 60 to $80 \%$ confluence.

\section{Cell viability assay}

Loss of cell viability was measured by the MTT assay. Cells were seeded at $1 \times 10^{4}$ cells/well in 96-well plates and allowed to grow in the growth medium for 24 hours. Cells were then treated with indicated concentrations of ABL-N for various time periods. After drug treatment, cells were incubated with $5 \mathrm{mg} / \mathrm{ml} \mathrm{MTT} \mathrm{for}$ two hours, and subsequently solubilized in DMSO. The absorbency at $570 \mathrm{~nm}$ was then measured using an enzyme-linked immunosorbent assay (ELISA) reader. The $\mathrm{IC}_{50}$ is the concentration agent that reduced the cell viability by $50 \%$ under experimental conditions. Experiments were repeated at least three times, and the data were expressed as the means $\pm \mathrm{SE}$.

\section{Nuclear staining assay}

After treatment, the cells were harvested, washed with phosphate-buffered saline (PBS), and fixed in 70\% ethanol for 30 minutes. The fixed cells were placed on slides and stained with $1 \mathrm{mg} / \mathrm{ml}$ DAPI for 15 minutes. Excess dye was washed off with PBS. Nuclear morphology was observed via a fluorescence microscope.

\section{Cell cycle analysis}

Cell cycle distribution was determined using flow cytometry analysis. Briefly, after treatment, cells were harvested with $0.25 \%$ trypsin, washed in PBS and centrifuged. The cells were fixed in ice-cold $75 \%$ ethanol for at least 30 minutes. Cells were washed and resuspended in PBS containing $25 \mu \mathrm{g} / \mathrm{ml}$ RNase and 0.5\% Triton X-100. Samples were then incubated with $50 \mu \mathrm{g} / \mathrm{ml}$ propidium iodide (PI) at $37^{\circ} \mathrm{C}$ for 30 minutes and analyzed in a flow cytometer (Becton Dickinson, San Jose, CA, USA).

\section{Cell apoptosis assay}

Cell apoptosis was measured by ELISA and flow cytometry, respectively. For ELISA, the cells seeded in 96well plates $\left(1 \times 10^{4}\right.$ cells/well $)$ were treated with ABL-N at $5,10,20$ and $40 \mu \mathrm{M}$ for 24 hours. Both floating and adherent cells were collected and lysed. Each concentration of ABL-N was repeated five times. The induction of apoptosis by the agent was evaluated with a Cell Death Detection ELISA ${ }^{\text {Plus }}$ kit (Roche Diagnostics, Mannheim, 
(a)<smiles>C=C1C(=O)OC2CC(C)=C(C(C)CCCOC(C)=O)C(O)C12</smiles>

(c)<smiles>COc1ccc2cc(C(C)C(=O)OC3C(C(C)CCCOC(C)=O)=C(C)CC4OC(=O)C(=O)C43)ccc2c1</smiles>

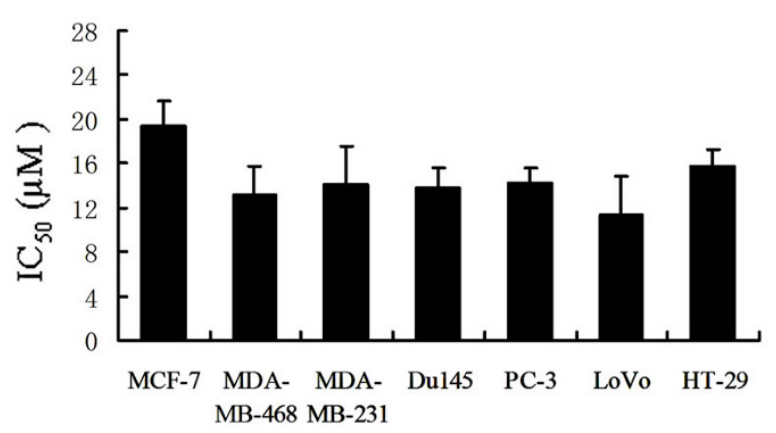

(b)

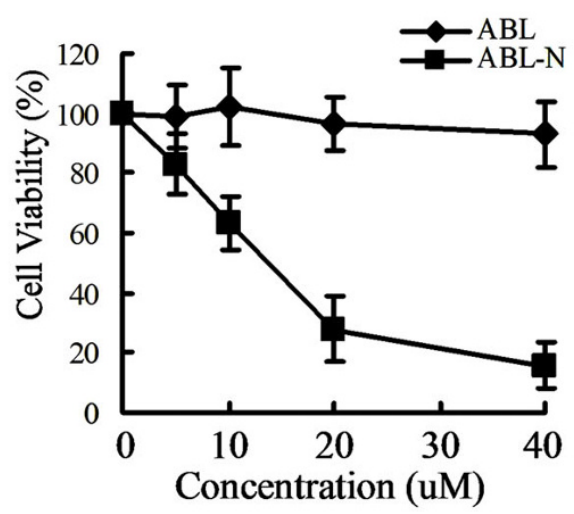

(d)
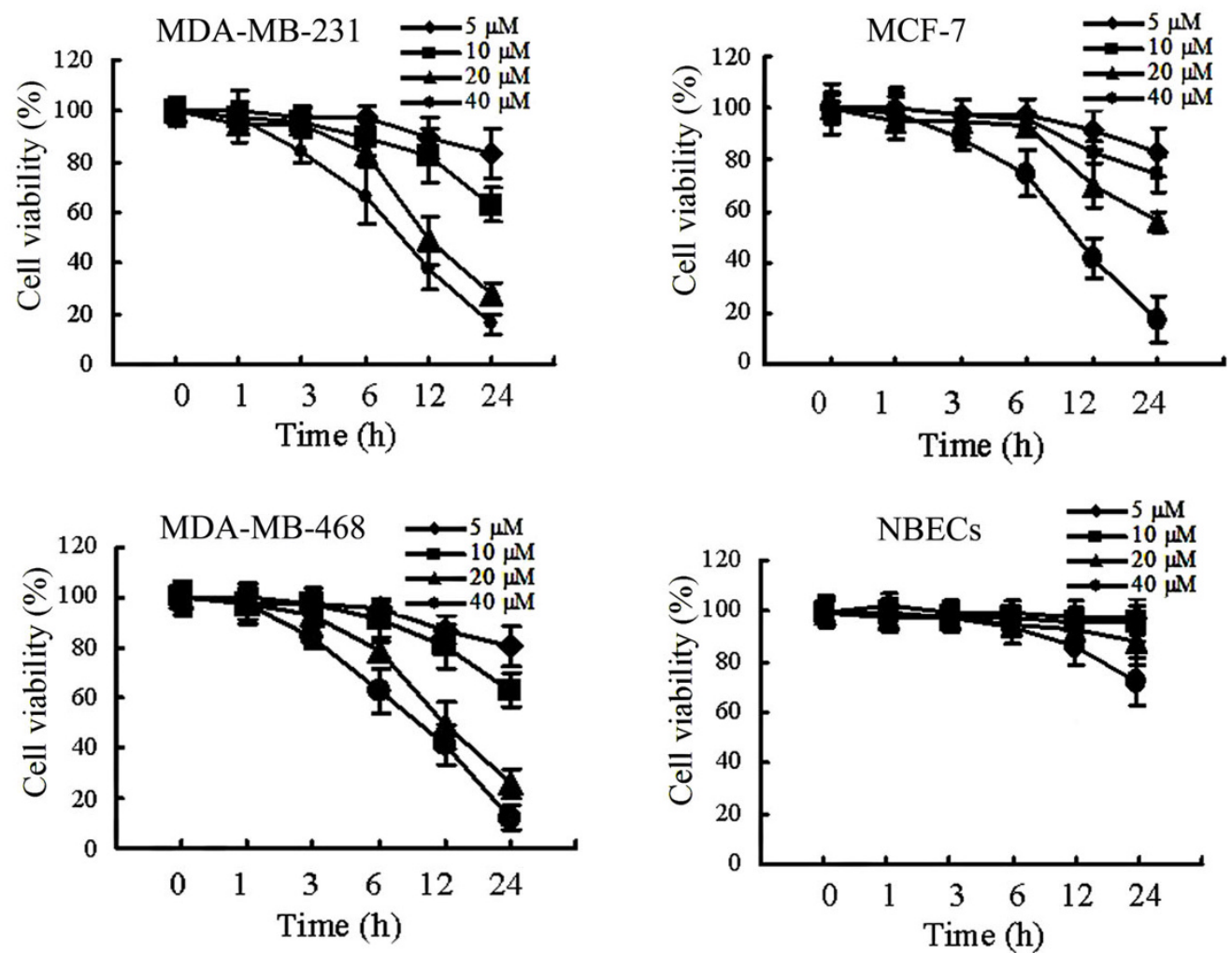

Figure 1 Effect of $A B L$ and ABL-N on cancer cell lines. (a) The chemical structures of ABL and ABL-N. (b) The differences of growth inhibition activity between ABL and ABL-N in MDA-MB-231 cells. (c) Effects of ABL-N on the viability of various cancer cell lines. Cells were treated with ABL-N for 24 hours and cell viability was determined by the MTT assay. The $I C_{50}$ is the concentration of ABL-N that reduced the cell viability by $50 \%$ under the experimental conditions $(n=6)$. (d) Time- and dose-dependent inhibition of cell viability by ABL-N treatment in MDA-MB-231, MCF-7, MDA-MB-468 and NBECs. Cells were treated with 5, 10, 20 or $40 \mu \mathrm{M}$ ABL-N for 1, 3, 6, 12 and 24 hours and cell viability was assessed by MTT assay $(n=6)$. Results represent the means \pm SE from three independent experiments. 
Germany) according to the manufacturer's instruction. Photometric enzyme immunoassay was used to quantitatively determine the formation of cytoplasmic histone-associated DNA fragments in the form of mononucleosomes and oligonucleosomes after apoptosis of the cells [22]. Measurements were made using an ELISA reader at $405 \mathrm{~nm}$ and the results were calculated as the ratio of the absorbance of the ABL-N-treated cells/absorbance of untreated cells.

For flow cytometry, briefly, after treatment, cells were collected and stained with Annexin V and PI staining using annexin V-FITC apoptosis kit (BD Biosciences, San Diego, CA, USA) according to the manufacturer's instruction. Early apoptotic (annexin V-positive and PInegative) cells were distinguished from late apoptotic (annexin V and PI double-positive) or necrotic (PI-positive) cells by a flow cytometric analysis.

\section{Western blot analysis}

The cellular lysates were subjected to Western blot analysis as described previously [16,23]. Scanned images were quantified using TotalLab TL120 software (Nonlinear Dynamics Ltd., Newscastle, United Kingdom).

\section{JNK activity assay}

Kinase activity of JNK was assayed with a nonradioactive assay kit according to enclosed manufacturer's procedures of Cell Signaling Technology. Briefly, after the cells were treated, the lysates were prepared using a lysis buffer (20 mM Tris ( $\mathrm{pH} 7.5)$ containing $150 \mathrm{mM} \mathrm{NaCl}$, $1 \mathrm{mM}$ EDTA, $1 \mathrm{mM}$ EGTA, 1\% Triton, $2.5 \mathrm{mM}$ sodium pyrophosphate, $1 \mathrm{mM} \beta$-glycerolphosphate, $1 \mathrm{mM}$ phenylmethylsulfonyl fluoride, $1 \mathrm{mM} \mathrm{Na} \mathrm{VO}_{4}$, and $1 \mu \mathrm{g} / \mathrm{ml}$ leupeptin). JNK in approximately $250 \mu \mathrm{g}$ of proteins in each sample lysate was pulled down selectively by an $\mathrm{N}$-terminal c-Jun (residues 1 to 89 ) fusion protein that were bound to glutathione sepharose beads at $4^{\circ} \mathrm{C}$ overnight with gentle rocking. Thereafter beads were washed twice with the lysis buffer and twice with kinase buffer (25 mM Tris (pH 7.5) containing 5 mM $\beta$-glycerolphosphate, $2 \mathrm{mM}$ dithiothreitol, $0.1 \mathrm{mM}$ sodium orthovanadate, and $10 \mathrm{mM} \mathrm{MgCl}_{2}$ ). After the washings, pellets were suspended in $50 \mu \mathrm{l}$ of kinase buffer supplemented with $200 \mu \mathrm{M}$ ATP and incubated for 30 minutes at $30^{\circ} \mathrm{C}$, during which c-Jun fusion proteins were phosphorylated by the activated JNK. JNK activity was analyzed by Western blotting using a specific phospho-c-Jun (Ser63) antibody. To determine the direct effect of ABL-N on JNK activity, in vitro cell-free kinase assays were also performed using purified recombinant GST-JNK1 fusion proteins (SignalChem, Richmond, British Columbia, Canada). ABL-N and purified GST-JNK1 fusion proteins were incubated for 12 hours and JNK activity assay was also performed in a similar manner.

\section{Measurement of caspase activities}

Cells were treated with ABL-N, and the caspase-2, caspase-3/7, caspase- 6 , caspase- 8 , and caspase- 9 activities in the cleared lysates were measured by using CaspaseGlo 2, Caspase-Glo 3/7, Caspase-Glo 6, Caspase-Glo 8, and Caspase-Glo 9 assays (Promega) according to the manufacturer's protocols. Luminescence was quantified using an ELISA reader. Blank values were subtracted, and increases in caspase activities were expressed as fold increase and calculated based on activities measured from untreated cells. Each sample was measured in triplicates.

\section{Transfection of siRNA}

siRNAs specific for JNK (JNK siRNA) and control siRNA were transiently transfected into cells using transfection reagent (Lipofectamine 2000; Invitrogen) according to the manufacturer's protocol. JNK protein levels were analyzed by Western blotting to confirm adequate silencing of the genes at 48 hours.

\section{Human breast tumor xenograft experiments}

The animal study was performed via a protocol approved by the governmental committee for animal research. Female BALB/c nude mice (four- to five-weeks old) were injected s.c. with MDA-MB-231 cells $(6 \times$ $10^{6}$ ) per mouse at both flanks. After six days, when tumors reached a size of about $100 \mathrm{~mm}^{3}$, mice were randomly grouped and treated by daily i.p. injection with ABL-N at concentrations of $15 \mathrm{mg} / \mathrm{kg}$ body weight, or vehicle (10\% DMSO, $10 \%$ ethanol in water). Mice were weighed at least twice a week to assess toxicity of the treatment, and the tumor size was measured every other day using calipers and their volumes were calculated according to a standard formula: width $^{2} \times$ length/ 2. Mice were sacrificed after 34 days of treatment when control tumors reached about $1,600 \mathrm{~mm}^{3}$.

\section{Statistical analysis}

Normal distribution of data was verified using the Shapiro-Wilk test. Statistical analysis was performed with the two-tailed, unpaired Student's $t$-test using SPSS 11.0 software. Results are given as means \pm SE. A value of $P$ $<0.05$ was considered statistically significant.

\section{Results}

$\mathrm{ABL}-\mathrm{N}$ reduces the viability of various carcinoma cell lines The inhibitory effects of $A B L$ and $A B L-N$ on various carcinoma cell lines were estimated using the MTT cellular survival assay. MDA-MB-231 cells were treated for 24 hours with various concentrations of $\mathrm{ABL}$ and $\mathrm{ABL}-$ $\mathrm{N}$, and cell viability was expressed as percentage of untreated cells. Figure $1 \mathrm{~b}$ showed that ABL did not affect cell viability at up to $40 \mu \mathrm{M}$; whereas this same 
concentration of ABL-N inhibited cell growth by $85 \%$. It indicated that ABL-N was dramatically more effective than ABL in inhibiting the growth of cells.

Next, we examined the effects of ABL-N on the viability of other human carcinoma cell lines. The results showed that ABL-N treatment inhibited cell growth with similar $\mathrm{IC}_{50}$ (approximately 12 to $20 \mu \mathrm{M}$ ) after a 24-hour treatment (Figure 1c). It indicated that ABL-N was a broad-spectrum inhibitory agent of the human carcinoma cells.

Furthermore, the sensitivity of three human breast cancer cells to ABL-N was assessed. These cells were chosen because they represent estrogen receptor (ER)negative (MDA-MB-231 and MDA-MB-468) and ERpositive (MCF-7) cell lines. The data showed that the inhibitory effects of ABL-N on cell viability occurred very fast. Treating MDA-MB-231 cells for 12 hours with 20 and $40 \mu \mathrm{M}$ ABL-N reduced cell viability by $51 \%$ and $62 \%$, respectively (Figure $1 \mathrm{~d}$ ). Similar results were observed in MDA-MB-468 and MCF-7 cells (Figure 1d). These results showed that there was no relationship between estrogen receptor status and cytotoxic effects of ABL-N.

Moreover, we assessed whether ABL-N had any differential sensitivity to normal versus cancer cells. As shown in Figure 1d, we found that the sensitivity of the NBECs to ABL-N was much lower, with ABL-N only having a significant effect on the viability ( $28 \%$ reduction, $P<0.05)$ of the NBECs following 24 hours of treatment at the $40 \mu \mathrm{M}$ dose, suggesting that ABL-N may have potential selectivity toward tumor cells.

\section{ABL-N arrests cells in $G_{2} / M$ phase of the cell cycle}

Because ABL-N can effectively inhibit cell viability, we reasoned that this effect might be attributable to its ability to interfere with the cell cycle. MDA-MB-231 cells were incubated with $20 \mu \mathrm{M} \mathrm{ABL}-\mathrm{N}$ for 6,12 and 24 hours, and the cell cycle analysis was done by PI uptake. Figure 2a shows that the ratio of cells in $G_{2} / M$ phase and the cells with hypodiploid DNA contents (sub-G G $_{1}$ were significantly accumulated over the treatment periods. In contrast, the cell cycle profile did not change over a 24-hour period in cells treated with the vehicle only (data not shown). Moreover, we also analyzed cell cycle in MDA-MB-468 and MCF-7 cells and found the $\mathrm{G}_{2} / \mathrm{M}$ arrest induced by $\mathrm{ABL}-\mathrm{N}$ as well (data not shown). Thus, it suggested that the inhibitory effect of ABL-N on breast cancer cells might be, at least in part, due to $\mathrm{G}_{2} / \mathrm{M}$ arrest of the cell cycle.

\section{ABL-N induces apoptosis in breast cancer cells}

We next analyzed whether the ABL-N-induced cell viability reduction in human breast cancer cells involved apoptosis. MDA-MB-231 cells were treated with $20 \mu \mathrm{M}$
ABL-N and apoptosis was assayed by two different methods. DAPI staining showed that the condensed and fragmented nuclei increased with ABL-N treatment (Figure 2b). Nucleosome fragmentation (an indicator of apoptosis) further determined by Cell Death Detection ELISA $^{\text {PLUS }}$ confirmed that cells treated for six hours with $20 \mu \mathrm{M}$ ABL-N underwent apoptosis, with the highest percentage of apoptotic cells seen at 24 hours (Figure 2c). In addition, an annexin V-binding assay showed that ABL-N treatment induced apoptosis but not necrosis in MDA-MB-231 cells (Figure 2d). We also obtained similar results when MDA-MB-468 and MCF-7 cells were treated with ABL-N (data not shown).

\section{ABL-N induces the activities of caspase in breast cancer cells}

To investigate the activation of caspases in ABL-Ninduced apoptosis, the proteolytic activation of caspase3 and caspase-9 was examined. As shown in Figure 3a, ABL-N $(20 \mu \mathrm{M})$ treatment resulted in a significant increase in the active form of cleaved caspase-3 and cleaved caspase- 9 in MDA-MB-231 cells. The cleavage products were detectable as early as six hours after exposure of cells to ABL-N. Furthermore, caspase activities were measured with Caspase-Glo assays. As shown in Figure 3b, treatment with ABL-N induced the activation of caspases-3/7, -8 and -9 in MDA-MB-231 cells. Under similar conditions, ABL-N also stimulated caspase- 2 and -6 activities in a lesser extent. Similar results were found in MDA-MB-468 cells (data not shown). However, in ER-positive cell MCF-7, the activities of caspase-3/7 and -9 were not affected by ABL-N, although caspase- 2 and -6 were activated to a level similar to that seen in MDA-MB-231 and MDA-MB-468 cells (data not shown). However, we found that caspase8 activity is significantly higher in MCF-7 cells treated with ABL-N, with the activity being increased by 2.8 fold of the untreated cells at 24 hours. The activation of caspases in MDA-MB-231 cells was further confirmed by detecting the degradation of PARP, which is an endogenous substrate of activated caspase- 3 and its cleavage is considered a hallmark of apoptosis [24-26]. Treatment of MDA-MB-231 cells with ABL-N resulted in cleavage of PARP to an $85 \mathrm{kDa}$ fragment (Figure 3c).

\section{Caspase inhibitors attenuate the induction of apoptosis by ABL-N}

To define the role of caspase activation in ABL-Ninduced apoptosis, we treated MDA-MB-231 cells with pan-caspase inhibitor z-VAD-fmk $(50 \mu \mathrm{M})$ and caspase3-specific inhibitor (z-DEVD-fmk) $(50 \mu \mathrm{M})$ before challenge with ABL-N $(20 \mu \mathrm{M})$. z-VAD-fmk pretreatment for one hour abrogated ABL-N-induced apoptosis as measured by the nucleosome fragmentation and the 
(a)

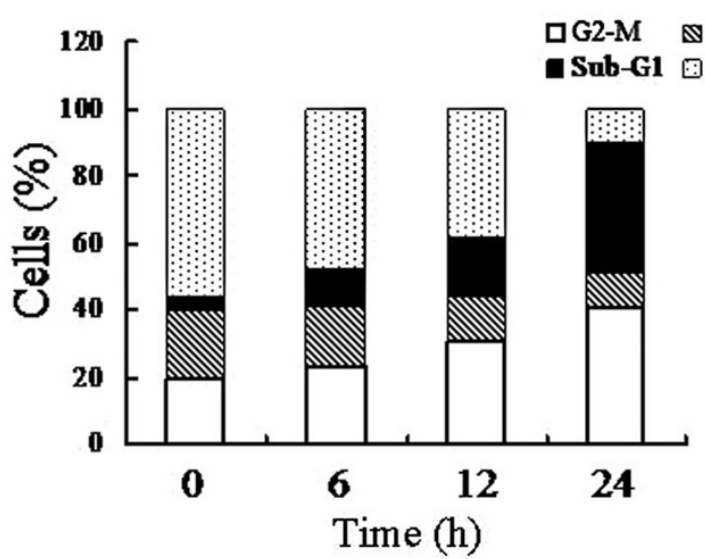

(b)

0

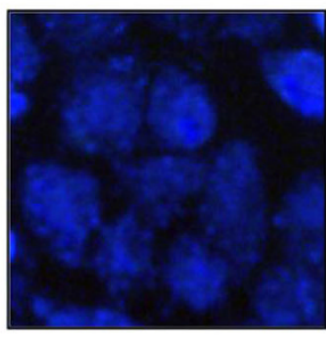

(c)

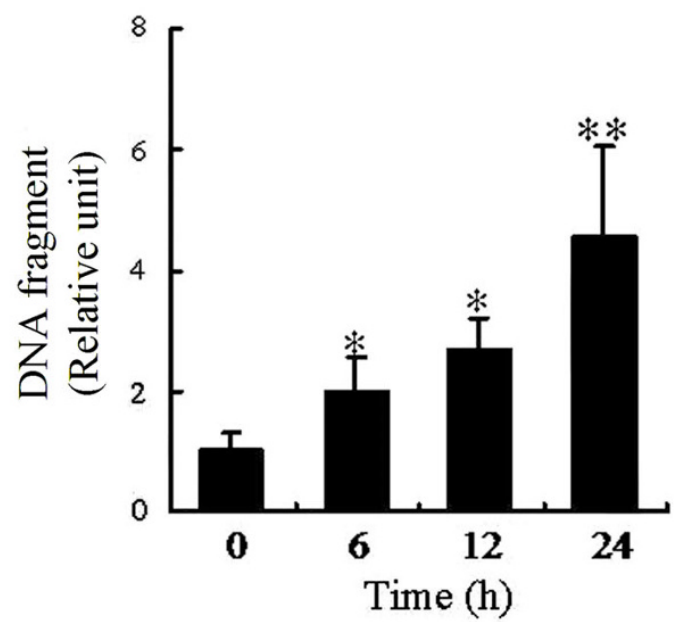

12
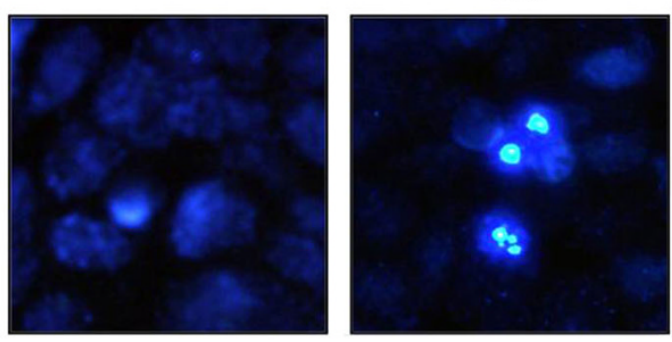

(d)

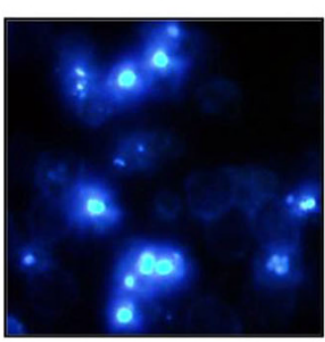

Time (h)

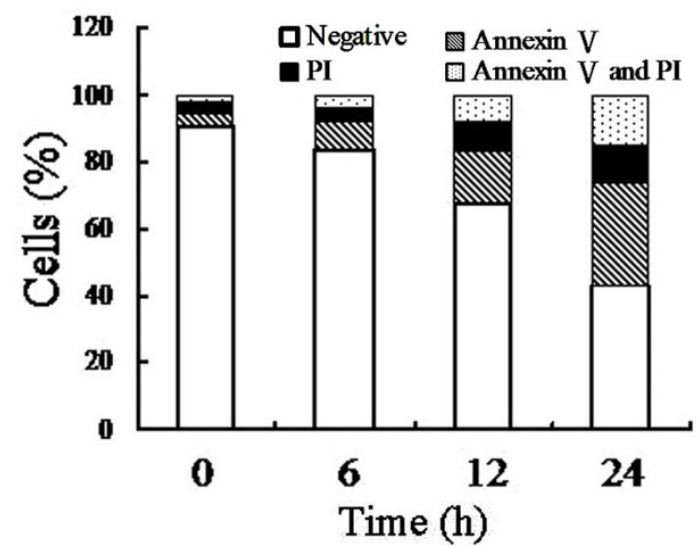

Figure 2 Effect of ABL-N on cell cycle progression and apoptosis in breast cancer cells. After treatment with $20 \mu \mathrm{M}$ ABL-N for indicated times, MDA-MB-231 cells were harvested. (a) The percentage of cell cycle distribution for cells done in triplicate with similar results. (b) Nuclear condensation was shown by DAPI-staining assay (magnification, $\times 100$ ). (c) DNA fragmentation was evaluated using a Cell Death Detection ELISA ${ }^{\text {Plus }}$ kit. The data are expressed as means \pm SE of three separate experiments. ${ }^{*} P<0.05,{ }^{*} P<0.01$, as compared with the group without $A B L-$ $\mathrm{N}$ treatment. (d) The apoptotic status was determined by Annexin V/PI staining method. Percentages of negative (viable) cells, annexin V-positive (early apoptotic) cells, Pl-positive (necrotic) cells, or annexin V and PI double-positive (late apoptotic) cells were shown (mean of three independent experiments) by a flow cytometric analysis. 
(a)

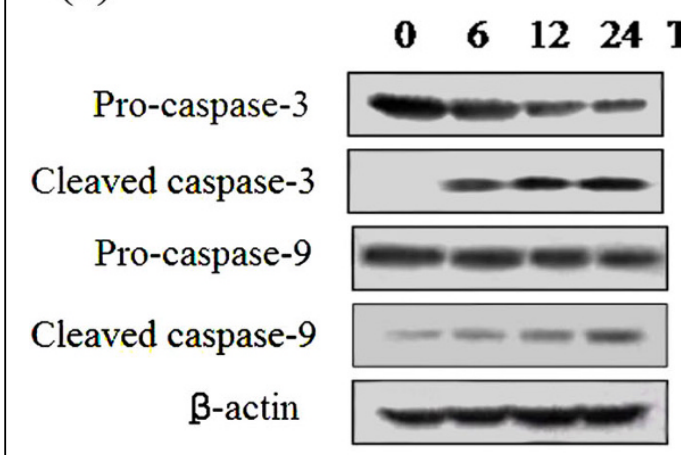

(b)

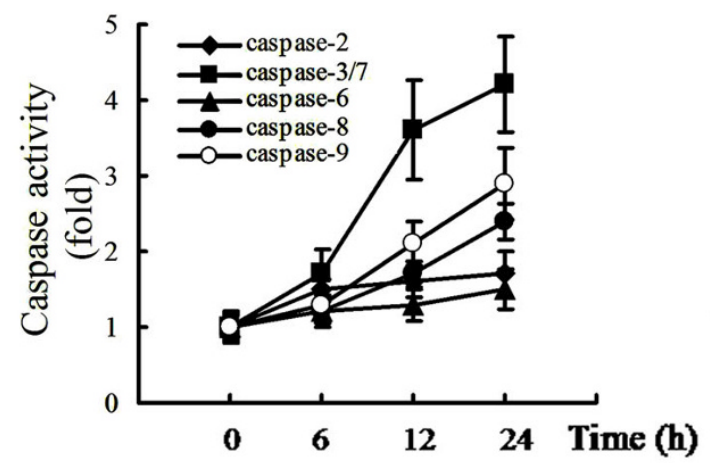

(c)

Full-length PARP Cleaved PARP

$\beta$-actin

h) (d)

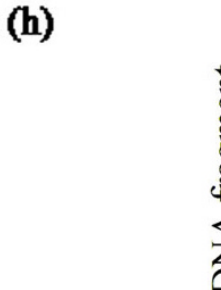

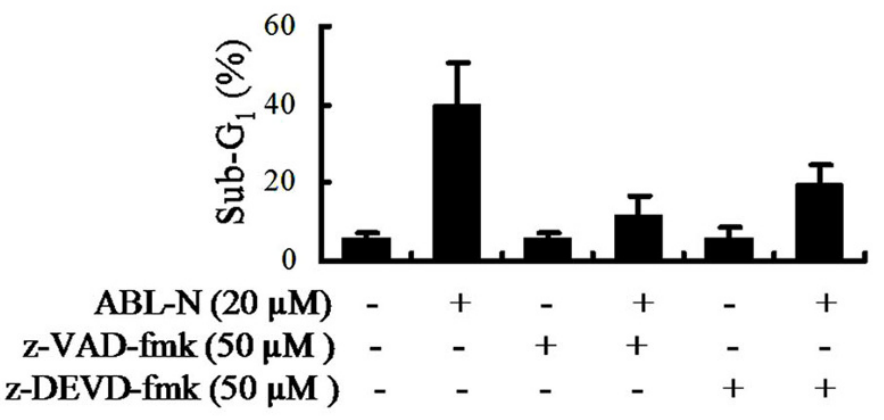
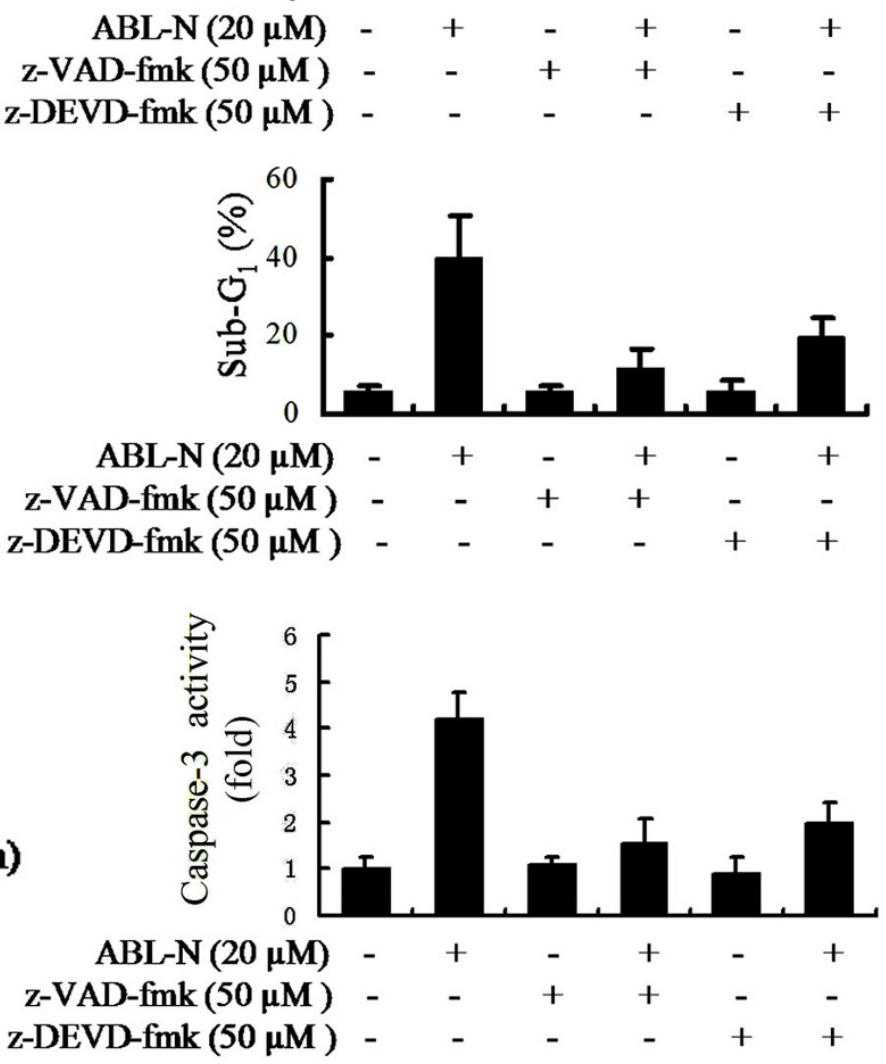

(e)

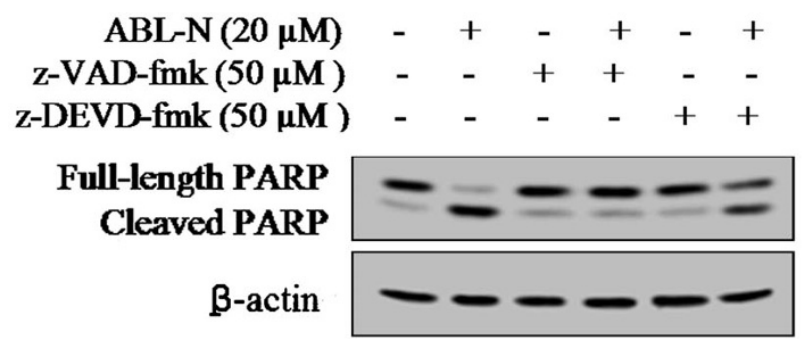

Figure 3 Induction of caspase activities by ABL-N. MDA-MB-231 cells were treated with $20 \mu \mathrm{M}$ ABL-N for indicated times. (a) Whole cell protein lysates were prepared and subjected to Western blot analysis for detection of cleavage of caspase-3 and caspase-9. (b) Induction of caspase activities by ABL-N in MDA-MB-231 cells. (c) Cleavage of PARP was induced by ABL-N. (d) Cells were pretreated with $50 \mu \mathrm{M}$ of either zVAD-fmk or z-DEVD-fmk for one hour, followed by $20 \mu \mathrm{M}$ ABL-N for 24 hours, and caspase-3 activity, DNA fragmentation and sub-G, DNA contents were determined. The data are expressed as means \pm SE of three separate experiments. (e) Abrogation of PARP cleavage by caspase inhibitors. 
appearance of sub- $\mathrm{G}_{1}$ cells (Figure $3 \mathrm{~d}$ ). Similar results were observed in both MDA-MB-468 and MCF-7 cells (data not shown). The caspase-3-specific inhibitor $\mathrm{z}$ DEVD-fmk also reduced ABL-N-induced apoptosis in MDA-MB-231 cells (Figure 3d). Moreover, both of the caspase inhibitors abolished caspase-3 activity in MDAMB-231 cells (Figure 3d). In addition, the cleavage of PARP was attenuated by pretreatment of cells with zVAD-fmk or with z-DEVD-fmk in MDA-MB-231 cells (Figure 3e). These results suggested that activation of a caspase cascade was essential for ABL-N-induced apoptosis in breast cancer cells.

\section{ABL-N modulates the expression of $\mathrm{BCl}-2$ family proteins in breast cancer cells}

Bcl-2 family of proteins, including Bcl-2 and Bcl-2related family members such as Bcl-xL, Bad and Bax, plays an important role in the regulation of apoptosis $[27,28]$. Thus, we evaluated the effects of ABL-N on the expression of anti-apoptotic protein Bcl-2 and the proapoptotic proteins Bax and Bad in breast cancer cells. Figure 4a showed a marked increase in the level of Bax and Bad, which started at six hours and peaked at 24 hours of treatment with ABL-N in MDA-MB-231 cells. In contrast, reduced $\mathrm{Bcl}-2$ protein appeared later at 12 hours. Then, the ratio of Bax and Bcl-2, which is the determining factor for the induction of apoptosis [29], was measured by a densitometric analysis of the bands. As shown in Figure 4b, ABL-N treatment resulted in a time-dependent increase in $\mathrm{Bax} / \mathrm{Bcl}-2$ ratio in MDAMB-231 cells that favors apoptosis.

\section{$A B L-N$ induces the activation of JNK and p38 signaling in breast cancer cells}

Activation of mitogen-activated protein (MAP) kinase is involved in many aspects of the control of cellular proliferation and apoptosis in response to a variety of extracellular stimulus [30-32]. We therefore examined the effects of ABL-N on the activation of several MAP kinase pathways. The cell lysates from ABL-N-treated MDA-MB-231 cells were subjected to Western blot analysis using antibodies that specifically recognize the phosphorylated forms of JNK, p38 and ERK. As shown in Figure $5 \mathrm{a}$ and $5 \mathrm{~b}, \mathrm{ABL}-\mathrm{N}$ treatment induced activation of JNK and p38 in a time-dependent manner.

The activation of JNK by ABL-N was further confirmed by the analysis of phosphorylation of its downstream substrate c-Jun (Figure 5a). It showed that c-Jun was phosphorylated following ABL-N treatment, which occurred over the same sustained period as JNK activation. However, no evident JNK and c-Jun phosphorylation could be observed within three hours after ABL-N treatment. Thus, JNK activation induced by ABL-N is a delayed and sustained, but not an early and transient, process. To gain further insight into the mechanism by which ABL-N treatment affects JNK, we assayed JNK activity in ABL$\mathrm{N}$-treated cells as well as the direct effect of ABL-N on GST-JNK1 fusion proteins activity. As depicted in Figure $5 \mathrm{c}$, JNK activity began to increase after treatment with 20 $\mu \mathrm{M}$ ABL-N for three hours and maximum activation was achieved 12 hours after treatment. In addition, using GST-JNK1 fusion proteins, we found that the JNK activity was unaffected by the presence of ABL-N (Figure $5 \mathrm{~d}$ ), indicating ABL-N activated JNK indirectly by activating signaling molecules located upstream in the JNK cascades. On the contrary, ERK was revealed to be constitutively activated in the cells and no significant change of ERK expression and phosphorylation was observed after ABL-N treatment (Figure 5e).

\section{Suppression of JNK antagonized ABL-N-induced caspase- 3 activity and PARP cleavage}

To determine the role of the activation of JNK and p38 in ABL-N-induced apoptosis, MDA-MB-231 cells were treated with the JNK inhibitor SP600125 or the p38 inhibitor SB203580 and their effects on cell apoptosis were examined. Additionally, we transfected MDA-MB231 cells with JNK siRNA or with a control siRNA for 48 hours. Transfection of JNK siRNA markedly reduced the expression of JNK protein compared with that in cells transfected with the control siRNA (Figure 6a). As shown in Figure $6 \mathrm{~b}$, reduction of cell viability by ABL-N was effectively abolished by SP600125, but SB203580 only had a slight effect on the decreased viability by ABL-N. The cells transfected with the JNK siRNA also blocked ABL-N-induced loss of cell viability. These results suggested that the activation of JNK signaling is responsible for the ABL-N-induced apoptosis. Similar results were further confirmed by flow cytometic analysis to determine the sub- $\mathrm{G}_{1}$ DNA contents (Figure 6c). Similarly, JNK inhibition by its specific inhibitor or siRNA could effectively antagonize ABL-N-induced caspase-3 activity and PARP cleavage (Figure 6d). Moreover, the stimulatory effect of ABL-N on c-Jun phosphorylation and JNK phosphorylation was not altered by SB203580, but significantly reduced by SP600125 (Figure 6e). These results suggested that activation of JNK, but not $\mathrm{p} 38$, was important for ABL-Ninduced apoptosis.

Furthermore, to address the possible role of caspase cleavage in the activation of JNK pathway in ABL-Ninduced apoptosis, we observed the effect of caspase inhibitors on JNK activation by ABL-N. The results indicated that $\mathrm{z}$-VAD-fmk $(50 \mu \mathrm{M})$ or $\mathrm{z}$-DEVD-fmk $(50 \mu \mathrm{M})$ pretreatment had no effect on c-Jun and JNK activation induced by ABL-N (Figure 6f), further suggesting that caspases were downstream targets of JNK signaling in response to ABL-N in breast cancer cells. 


\section{(a)}

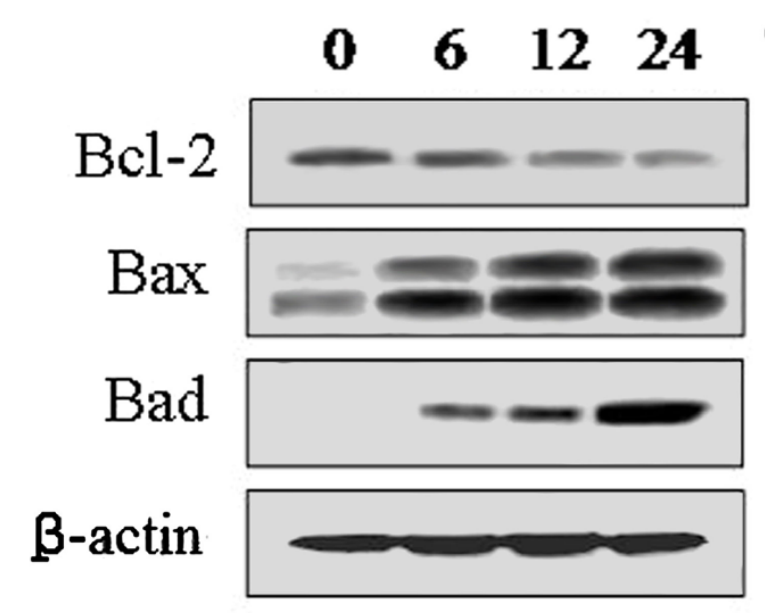

(b)

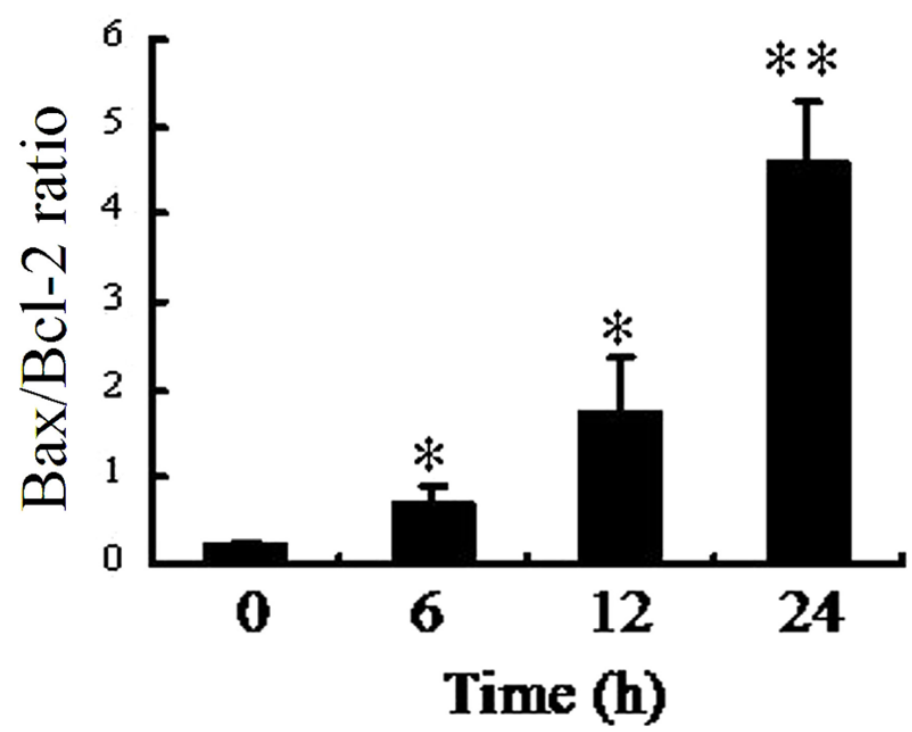

Figure 4 Effects of ABL-N on the expression of Bcl-2 family. (a) Treatment of ABL-N decreased the level of the anti-apoptotic protein BCl-2, but increased the expression of the pro-apoptotic proteins Bax and Bad in MDA-MB-231 cells. (b) Effect of ABL-N on the Bax/BCl-2 ratio in MDAMB-231 cells. The data obtained from the Western blot analysis of Bax and BCl-2 were used to evaluate the effect of ABL-N on the Bax/BCl-2 ratio. The densitometric analysis of Bax and BCl-2 bands was performed using TotalLab TL120 software, and the data (relative density normalized to $\beta$-actin) were plotted as Bax/BCl-2 ratio. Data are expressed as means $\pm \mathrm{SE}$ of three separate experiments with similar results. ${ }^{*} P<0.05$, ${ }^{*} P<0.01$, as compared with the group without ABL-N treatment. 


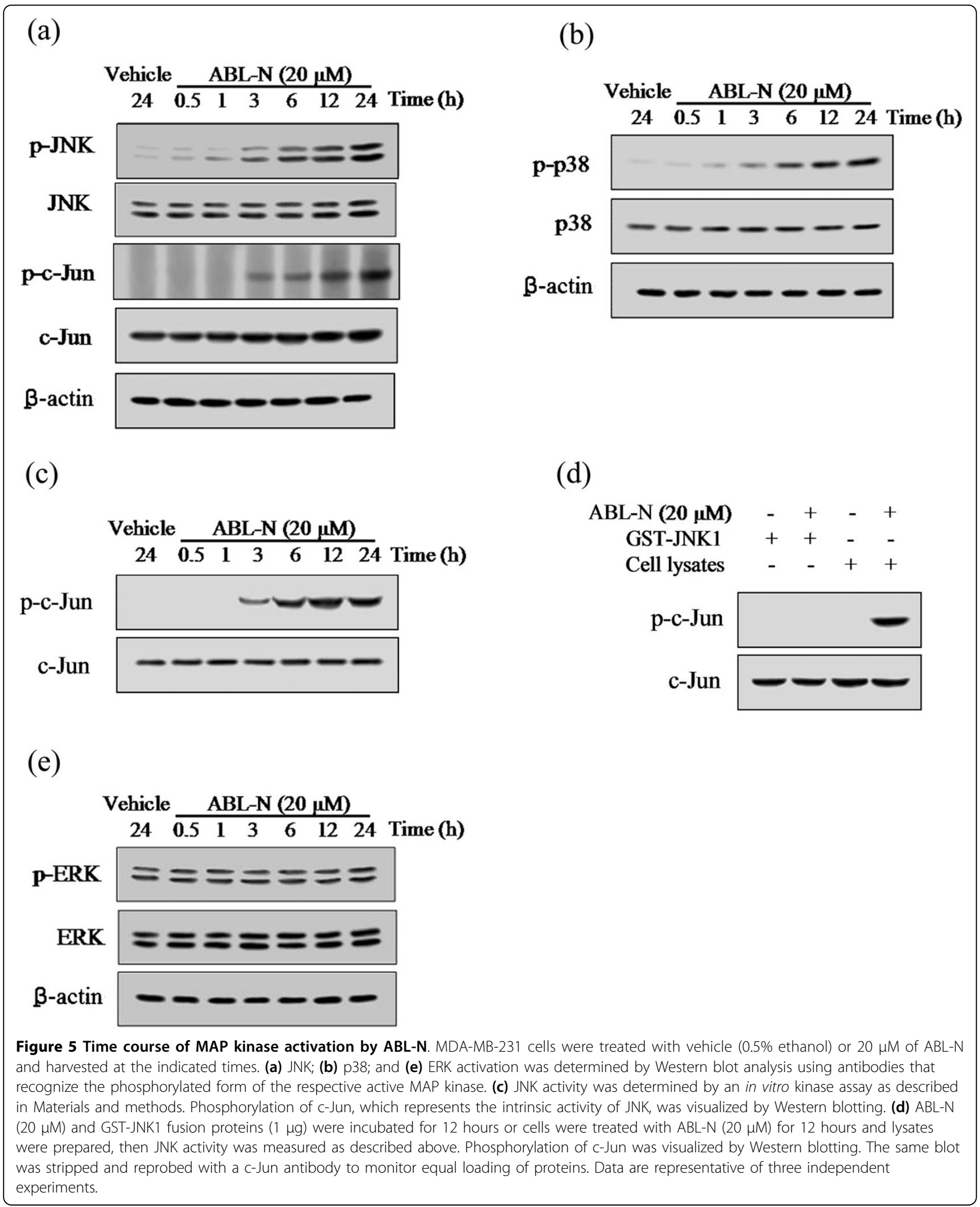


(a)

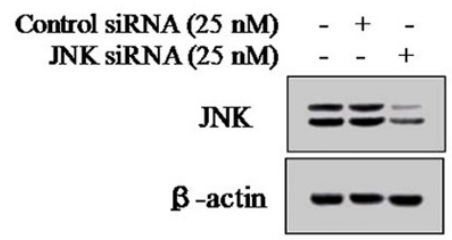

(c)

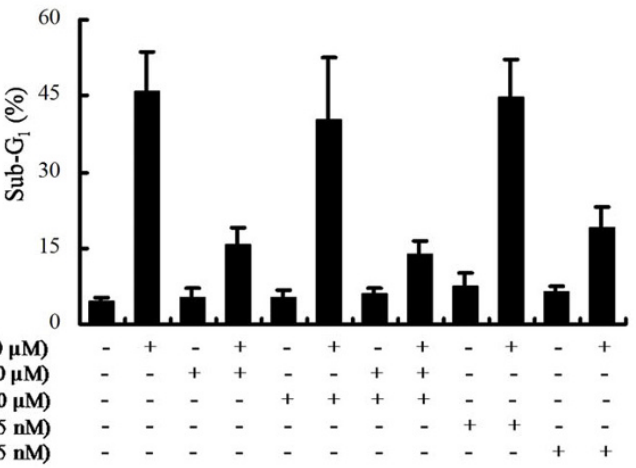

(b)

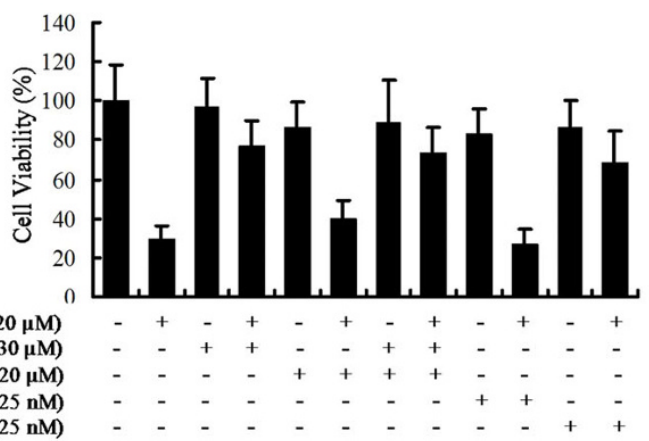

(e)

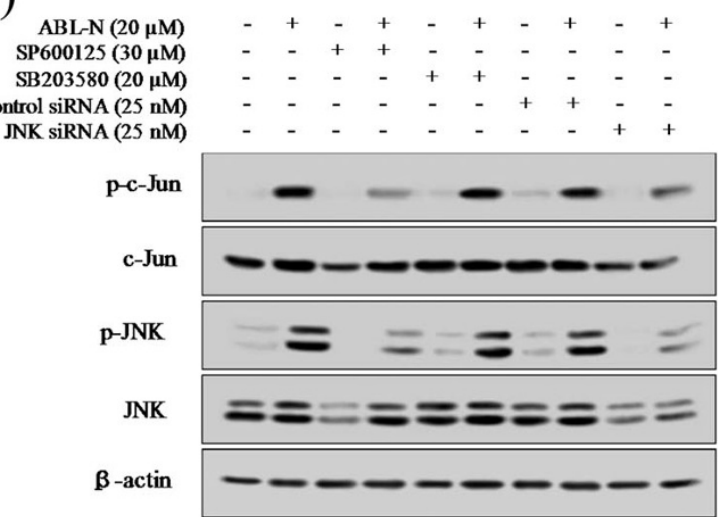

(f)

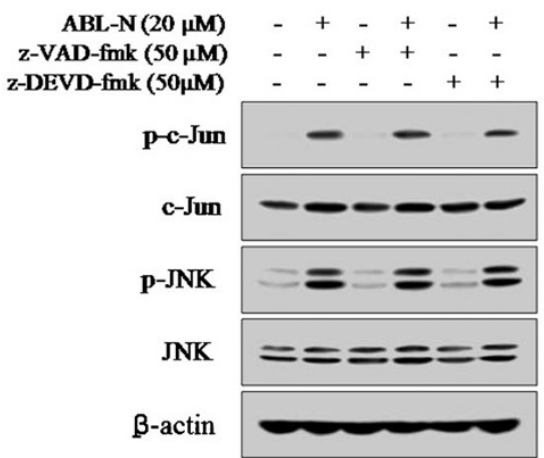

(d)
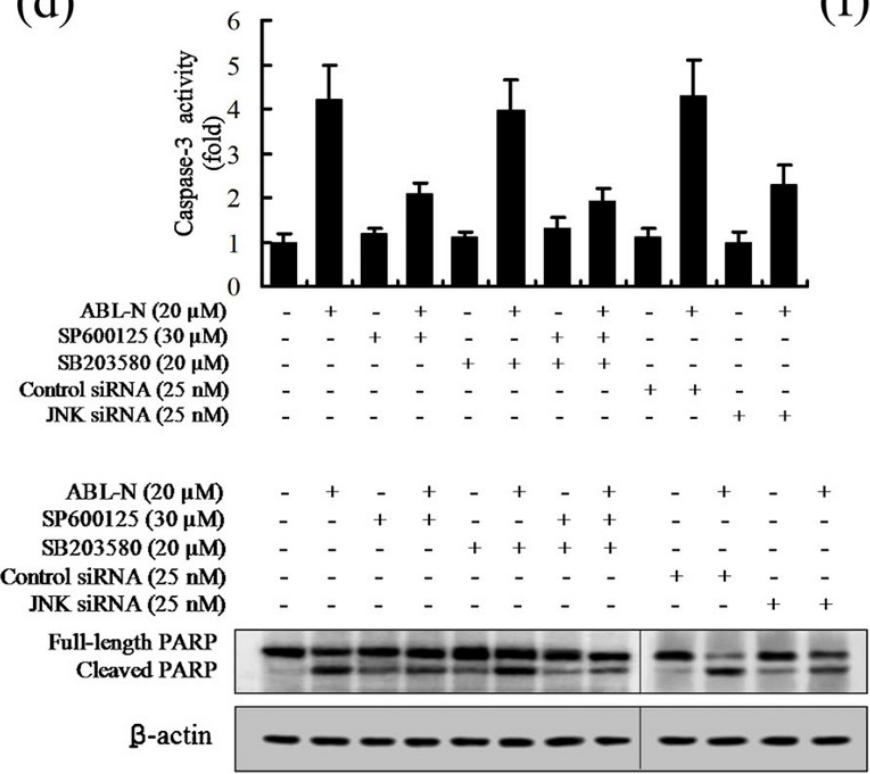

Figure 6 Role of JNK in ABL-N-induced apoptosis. MDA-MB-231 cells were incubated with ABL-N (20 $\mu$ M) and either SB203580 (20 $\mu$ M) or SP600125 (30 MM), or a combination of both for 24 hours. (a) MDA-MB-231 cells were transfected with JNK siRNA (25 nM) or control siRNA $(25 \mathrm{nM})$ for 48 hours, and cell lysates were subjected to Western blot with antibodies to JNK. (b) ABL-N-induced cell death was abrogated by inhibition of JNK using MTT assay. (c) Sub G DNA content was analyzed by flow cytometry. (d) Caspase-3 activity was determined by CaspaseGlo assay and the cleavage of PARP was analyzed via Western blotting. Data are expressed as the means \pm SE of three independent experiments. (e) Effect of MAP kinase inhibitors on ABL-N-induced JNK activation. (f) Effect of caspase inhibitors on JNK activation. Cells pretreated with or without z-VAD-fmk $(50 \mu \mathrm{M})$ or z-DEVD-fmk (50 $\mu \mathrm{M}$, one hour) were further incubated with vehicle or $20 \mu \mathrm{M}$ ABL-N for 24 hours. Data are representative of three independent experiments. 


\section{ABL-N inhibits the growth of human breast cancer xenografts}

Because ABL-N treatment showed the effective growth inhibition in cultured breast cancer cells, we subsequently carried out in vivo study using MDA-MB-231-derived cancer xenografts in nude mice. As shown in Figure 7, the i.p. treatment with ABL-N (15 mg/kg) caused a significant inhibition of tumor growth as early as 20 days after treatment and persisted after 34 days. Furthermore, animals showed no body weight loss, decreased activity, or anorexia (data not shown). This initial in vivo experiment suggested that ABL-N might be an effective anticancer agent at dosages that induced negligible toxic effects.

\section{Discussion}

Induction of apoptosis in malignant cells is a critical property of chemopreventive agents. ABL, which has been shown to be potently anti-tumorigenic, has proapoptotic features in many carcinoma cell types [17-19]. We modified ABL to improve potency and pharmacologic characteristics, and obtained a highly active derivative ABL-N, which showed exceptional anti-proliferative activity against several human cancer cell types. The differences in biological activity of ABL and ABL-N could be attributed to the difference in their structures (Figure 1a). The increased activity of ABL-N could be, most likely, attributed to (S)-2-(6-methoxynaphthalen-2-yl) propionyl- side chain of ABL-N, which is substituted with hydroxyl group at C-6 in ABL. The purpose of this study was to investigate the possible role of caspase activation and JNK signaling in ABL-N-induced apoptosis in ER-positive and ER-negative breast cancer cells.
Apoptosis is governed by a complex network of antiapoptotic and pro-apoptotic effector molecules. Among proteins implicated in control of apoptosis, members of the Bcl-2 family have been demonstrated to be associated with the mitochondrial membrane integrity [33]. They can activate or inhibit the release of downstream factors such as cytochrome $c$ which leads to the activation of caspase- 3 and PARP in the execution of apoptosis [34]. Bax exerts pro-apoptotic activity by translocation from the cytosol to the mitochondria, where it induces cytochrome $c$ release, while $\mathrm{Bcl}-2$ exerts its anti-apoptotic activity, at least in part, by inhibiting the translocation of Bax to the mitochondria $[35,36]$. Notably, the ratio of pro- and anti-apoptotic protein expression, such as $\mathrm{Bax} / \mathrm{Bcl}-2$, is critical for the induction of apoptosis, and it decides the susceptibility of cells to undergo apoptosis [29]. In the present study, we showed that treatment of the MDA-MB-231 cells with $A B L-N$ resulted in significant decrease in the Bcl-2 protein and increase in the Bax protein, thus shifting the $\mathrm{Bax} / \mathrm{Bcl}-2$ ratio in favor of apoptosis.

Caspases are known to act as key mediators of apoptosis and to contribute to the apoptotic morphology through the cleavage of various cellular substrates. Caspase- 3 is an executioner member that can cleave specific substrates such as PARP $[37,38]$. Here, the results that caspase- 3 activation was accompanied by PARP cleavage in MDA-MB-231 and MDA-MB-468 ER-negative cells indicated that caspase-3 might play a key role as an important executioner in ABL-N-induced apoptosis in these cell lines. It was further substantiated by the data that caspase-3 inhibitor z-DEVD-fmk suppressed cell

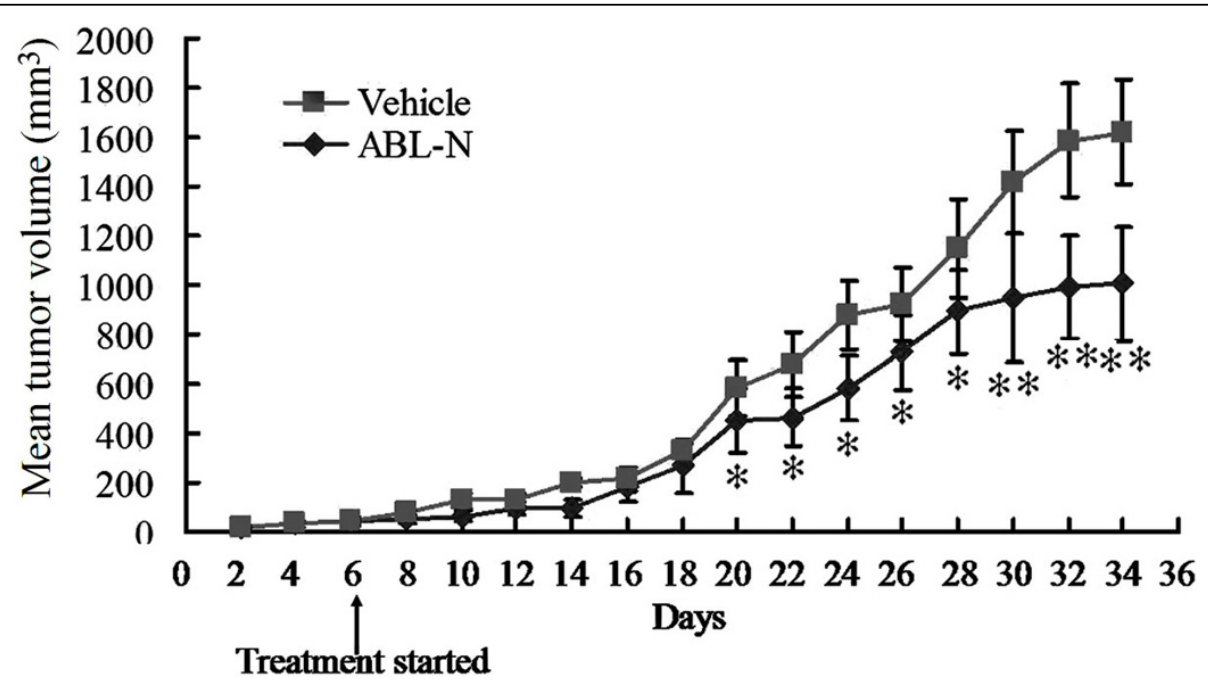

Figure $\mathbf{7}$ The effect of ABL-N on the growth of MDA-MB-231 xenografts. Female nude mice bearing MDA-MB-231 tumor xenografts were treated with ABL-N (15 mg/kg), or vehicle (10\% DMSO, 10\% ethanol in water), and tumors were measured with calipers on alternate days. Points $=$ mean tumor volume in each experimental group containing six mice; bars $=\mathrm{SD} ;{ }^{*}, P<0.05 ;{ }^{*}, P<0.01$, compared with vehicle treated group. 
apoptosis induced by ABL-N. However, the absence of caspase-3 activation in MCF-7 ER-positive cells [39] raised the possibility that ABL-N might induce apoptosis in MCF-7 cells through caspase-3-independent pathway. It is demonstrated that curcumin and tributyrin could induce apoptosis but independent of caspase- 3 activation in MCF-7 cells [40,41]. Therefore, other caspases might take part in ABL-N-induced apoptosis in MCF-7 cells. This was supported by our results that the pancaspase inhibitor z-VAD-fmk could abrogate ABL-Ninduced nucleosome fragmentation and the appearance of sub- $\mathrm{G}_{1}$ cells. Our study further found that ABL-N induced significant activation of caspase- 8 in the breast cancer cells, suggesting that ABL-N may activate the death receptor pathway and induce the expression of death receptors or death ligands such as tumor necrosis factor- $\alpha$ and Fas ligand [42]. Thus, death receptor- or mitochondria-mediated activation of the caspase may be a potential mechanism underlying ABL-N-induced apoptosis in breast cancer cells. Recently, it was reported that another factor contributing to the activation of caspase is related to the inhibitors of apoptosis proteins (IAPs), which have been revealed to inhibit apoptosis due to their function as direct inhibitors of caspases $[43,44]$. Many anticancer agents such as curcumin [45], epigallocatechin [46] and esculetin [47], have been shown to interfere with IAPs and increase apoptosis rate. Consequently, we can hypothesize that ABL-N possibly invokes similar pathways and further study is necessary to investigate the precise mechanisms responsible.

It is reported that the JNK pathway is very important in cell apoptosis induced by various cytotoxic compounds $[30,46,47]$. Studies reported here showed that ABL-N induced activation of JNK beginning one hour after ABL$\mathrm{N}$ treatment and produced a sustained elevation for at least 24 hours in MDA-MB-231 cells, which is much earlier than the activation of caspase and the apoptosis. Moreover, the JNK activation correlated with the increased phosphorylated c-Jun, which appeared to play a significant role in ABL-N-induced apoptosis and to correlate with the activation of caspase. ABL-N could also activate JNK in cells as monitored by JNK activity assay. Several JNK isoforms, including JNK2 and JNK3, had kinase activity in the absence of any activating upstream kinase, which showed autophosphorylation activity resulting in constitutive activation [48]. Therefore, we use recombinant JNK1 proteins to determine the direct effects of ABL-N on JNK. However, ABL-N did not activate GST-JNK1 fusion proteins in vitro kinase activity assay, indicating ABL-N might act on JNK by the upstream activators. Many studies have reported that activation of JNK by its upstream kinases or molecules is critical for its function. A number of factors, such as
MAP kinase kinase 4 (MKK4) [49], epidermal growth factor receptor (EGFR) [50], insulin growth factor receptor (IGFR) [51] and spleen tyrosine kinase (SYK) [52], have been implicated in the activation of JNK. Thus, further studies will be required to determine how ABL-N acts upstream of JNK. In addition, our data showed that neither of the caspase inhibitors prevented ABL-Ninduced JNK activation, while JNK-specific inhibitor or JNK siRNA, at least partially inhibited ABL-N-induced apoptosis, indicating that JNK is upstream of caspases in ABL-N-initiated apoptosis. Therefore, the results showed that both the caspases and JNK pathway were necessary to ABL-N-induced apoptosis in breast cancer cells because interfering with either pathway could attenuate apoptosis. Specifically, it was important to note that interference with JNK using the specific inhibitor or siRNA did not result in total abolition of ABL-N-induced cell death, as shown by MTT and flow cytometry assays. This may contribute to partial inhibition of JNK by SP600125 or siRNA, since JNK inhibition led to significant but not total reduction in phosphorylation of c-Jun. Thus, it is likely that JNK-independent mechanisms may participate in ABL-N-induced apoptosis.

\section{Conclusions}

In summary, our studies suggest for the first time that ABL-N significantly induces apoptosis in breast cancer cells. This induction is associated with the activation of caspases and JNK signaling pathways. Moreover, ABL-N treatment caused a significant inhibition of tumor growth in vivo. Therefore, it is thought that ABL-N might be a potential drug for use in breast cancer prevention and intervention.

\section{Abbreviations}

ELISA: enzyme-linked immunosorbent assay; ER: estrogen receptor; ERK: extracellular signal-regulated kinase; IAP: inhibitors of apoptosis protein; JNK: c-Jun $\mathrm{NH}_{2}$-terminal kinase; MAP kinase: mitogen-activated protein kinase; MTT: 3-(4,5-dimethylthiazol-2-yl)-2,5-diphenyltetrazoliumbromide; PARP: poly (ADP-ribose) polymerase; p38: p38 MAP kinase; PBS: phosphate-buffered saline; siRNA: small interfering RNA.

\section{Acknowledgements}

This research was supported by the National Natural Science Foundation of P.R China (No. 30971457 and 30973820) and Hebei Province Natural Science Foundation of P.R. China (C2008001049).

\section{Author details}

${ }^{1}$ Department of Biochemistry and Molecular Biology, Institute of Basic Medicine, Hebei Medical University, No.361, Zhongshan East Road, Shijiazhuang, 050017, China. ${ }^{2}$ College of Pharmacy, Hebei Medical University, No.361, Zhongshan East Road, Shijiazhuang, 050017, China.

\section{Authors' contributions}

$B L$ designed the study, carried out many of the experiments, and drafted the manuscript. RHS, JJW and YPZ participated in the design of the study and data interpretation. MH, DQZ and JKW led the conception and design of the study and the revisions to the manuscript and supervised this research project. All authors read and approved the final manuscript. 


\section{Competing interests}

The authors declare that they have no competing interests.

Received: 23 July 2009 Revised: 20 December 2009

Accepted: 25 January 2010 Published: 25 January 2010

\section{References}

1. Mellstedt H: Cancer initiatives in developing countries. Ann Oncol 2006, 17:viii24-viii31.

2. Althuis MD, Dozier JM, Anderson WF, Devesa SS, Brinton LA: Global trends in breast cancer incidence and mortality 1973-1997. Int J Epidemiol 2005, 34:405-412.

3. Wu CC, Chan ML, Chen WY, Tsai CY, Chang FR, Wu YC: Pristimerin induces caspase-dependent apoptosis in MDA-MB-231 cells via direct effects on mitochondria. Mol Cancer Ther 2005, 4:1277-1285.

4. Garcia-Carbonero R, Supko JG: Current perspectives on the clinical experience, pharmacology, and continued development of the camptothecins. Clin Cancer Res 2002, 8:641-661.

5. Rowinsky EK, Donehower RC: Paclitaxel (taxol). N Engl J Med 1995, 332:1004-1014.

6. Zhu JY, Lavrik IN, Mahlknecht U, Giaisi M, Proksch P, Krammer PH, LiWeber M: The traditional Chinese herbal compound rocaglamide preferentially induces apoptosis in leukemia cells by modulation of mitogen-activated protein kinase activities. Int I Cancer 2007, 121:1839-1846.

7. Huang M, Gao H, Chen Y, Zhu H, Cai Y, Zhang X, Miao Z, Jiang H, Zhang J, Shen H, Lin L, Lu W, Ding J: Chimmitecan, a novel 9-substituted camptothecin, with improved anticancer pharmacologic profiles in vitro and in vivo. Clin Cancer Res 2007, 13:1298-1307.

8. Tamvakopoulos C, Dimas K, Sofianos ZD, Hatziantoniou S, Han Z, Liu ZL, Wyche $\mathrm{JH}$, Pantazis P: Metabolism and anticancer activity of the curcumin analogue, dimethoxycurcumin. Clin Cancer Res 2007, 13:1269-1277.

9. Liu J, Zhou W, Li SS, Sun Z, Lin B, Lang YY, He JY, Cao X, Yan T, Wang L, Lu J, Han YH, Cao Y, Zhang XK, Zeng JZ: Modulation of orphan nuclear receptor Nur77-mediated apoptotic pathway by acetylshikonin and analogues. Cancer Res 2008, 68:8871-8880.

10. Wang Z, Qiu J, Guo TB, Liu A, Wang Y, Li Y, Zhang JZ: Anti-inflammatory properties and regulatory mechanism of a novel derivative of artemisinin in experimental autoimmune encephalomyelitis. J Immunol 2007, 179:5958-5965.

11. Zhang M, Huang J, Xie X, Holman CD: Dietary intakes of mushrooms and green tea combine to reduce the risk of breast cancer in Chinese women. Int I Cancer 2009, 124:1404-1408.

12. Razis ED, Fountzilas G: Paclitaxel: epirubicin in metastatic breast cancer-a review. Ann Oncol 2001, 12:593-598.

13. Hainsworth JD, Greco FA: Etoposide: twenty years later. Ann Oncol 1995, 6:325-341.

14. Jordan MA, Thrower D, Wilson L: Mechanism of inhibition of cell proliferation by Vinca alkaloids. Cancer Res 1991, 51:2212-2222

15. Liu B, Han M, Wen JK: Acetylbritannilactone Inhibits neointimal hyperplasia after balloon injury of rat artery by suppressing nuclear factor-kappa B activation. J Pharmacol Exp Ther 2008, 324:292-298.

16. Liu YP, Wen JK, Zheng B, Zhang DQ, Han M: Acetylbritannilactone suppresses lipopolysaccharide-induced vascular smooth muscle cell inflammatory response. Eur J Pharmacol 2007, 577:28-34.

17. Bai N, Lai CS, He K, Zhou Z, Zhang L, Quan Z, Zhu N, Zheng QY, Pan MH, Ho CT: Sesquiterpene lactones from Inula britannica and their cytotoxic and apoptotic effects on human cancer cell lines. J Nat Prod 2006, 69:531-535

18. Rafi MM, Bai NS, Chi Tang H, Rosen RT, White E, Perez D, Dipaola RS: A sesquiterpenelactone from Inula britannica induces anti-tumor effects dependent on Bcl-2 phosphorylation. Anticancer Res 2005, 25:313-318.

19. Park EJ, Kim J: Cytotoxic sesquiterpene lactones from Inula britannica. Planta Med 1998, 64:752-754.

20. Easty GC, Easty DM, Monaghan P, Ormerod MG, Neville AM: Preparation and identification of human breast epithelial cells in culture. Int J Cancer 1980, 26:577-584.

21. Edwards PA, Brooks IM, Bunnage HJ, Foster AV, Ellison ML, O'Hare MJ: Clonal analysis of expression of epithelial antigens in cultures of normal human breast. J Cell Sci 1986, 80:91-101.
22. Adhami VM, Aziz MH, Mukhtar $\mathrm{H}$, Ahmad N: Activation of prodeath Bcl-2 family proteins and mitochondrial apoptosis pathway by sanguinarine in immortalized human HaCaT keratinocytes. Clin Cancer Res 2003, 9:3176-3182.

23. Han M, Wen JK, Zheng B, Cheng Y, Zhang C: Serum deprivation results in redifferentiation of human umbilical vascular smooth muscle cells. Am J Physiol Cell Physiol 2006, 291:C50-58.

24. Lowe SW, Lin AW: Apoptosis in cancer. Carcinogenesis 2000, 21:485-495.

25. Jiang C, Wang Z, Ganther H, Lu J: Caspases as key executors of methyl selenium-induced apoptosis (anoikis) of DU-145 prostate cancer cells. Cancer Res 2001, 61:3062-3070.

26. Kaufmann SH, Desnoyers S, Ottaviano Y, Davidson NE, Poirier GG: Specific proteolytic cleavage of poly(ADP-ribose) polymerase: an early marker of chemotherapy-induced apoptosis. Cancer Res 1993, 53:3976-3985.

27. Elmore S: Apoptosis: a review of programmed cell death. Toxicol Pathol 2007, 35:495-516.

28. Willis $\mathrm{S}$, Day $\mathrm{CL}$, Hinds MG, Huang DC: The Bcl-2-regulated apoptotic pathway. J Cell Sci 2003, 116:4053-4056.

29. Cory S, Adams JM: The Bcl2 family: regulators of the cellular life-or-death switch. Nat Rev Cancer 2002, 2:647-656.

30. Wada T, Penninger JM: Mitogen-activated protein kinases in apoptosis regulation. Oncogene 2004, 23:2838-2849.

31. Kyriakis JM, Avruch J: Mammalian mitogen-activated protein kinase signal transduction pathways activated by stress and inflammation. Physiol Rev 2001, 81:807-869.

32. Xia Z, Dickens M, Raingeaud J, Davis RJ, Greenberg ME: Opposing effects of ERK and JNK-p38 MAP kinases on apoptosis. Science 1995, 270:1326-1331.

33. Adams JM, Cory $\mathrm{S}$ : The $\mathrm{BCl}-2$ protein family: arbiters of cell survival. Science 1998, 281:1322-1326.

34. Tafani M, Schneider TG, Pastorino JG, Farber JL: Cytochrome c-dependent activation of caspase-3 by tumor necrosis factor requires induction of the mitochondrial permeability transition. Am J Pathol 2000, 156:2111-2121.

35. Wolter KG, Hsu YT, Smith CL, Nechushtan A, Xi XG, Youle RJ: Movement of Bax from the cytosol to mitochondria during apoptosis. J Cell Biol 1997, 139:1281-1292.

36. Wang $X$ : The expanding role of mitochondria in apoptosis. Genes Dev 2001, 15:2922-2933.

37. Hunot S, Flavell RA: Apoptosis. Death of a monopoly?. Science 2001, 292:865-866.

38. Nicholson DW, Thornberry NA: Apoptosis. Life and death decisions. Science 2003, 299:214-215.

39. Janicke RU, Sprengart ML, Wati MR, Porter AG: Caspase-3 is required for DNA fragmentation and morphological changes associated with apoptosis. J Biol Chem 1998, 273:9357-9360.

40. Piwocka K, Bielak-Mijewska A, Sikora E: Curcumin induces caspase-3independent apoptosis in human multidrug-resistant cells. Ann N Y Acad Sci 2002, 973:250-254.

41. Heerdt BG, Houston MA, Anthony GM, Augenlicht LH: Initiation of growth arrest and apoptosis of MCF-7 mammary carcinoma cells by tributyrin, a triglyceride analogue of the short-chain fatty acid butyrate, is associated with mitochondrial activity. Cancer Res 1999, 59:1584-1591.

42. Nagata S: Fas ligand-induced apoptosis. Annu Rev Genet 1999, 33:29-55.

43. Liu B, Han M, Wen JK, Wang L: Livin/ML-IAP as a new target for cancer treatment. Cancer Lett 2007, 250:168-176.

44. Wang L, Zhang Q, Liu B, Han M, Shan B: Challenge and promise: roles for Livin in progression and therapy of cancer. Mol Cancer Ther 2008, 7:3661-3669.

45. Woo JH, Kim YH, Choi YJ, Kim DG, Lee KS, Bae JH, Min DS, Chang JS, Jeong YJ, Lee YH, Park JW, Kwon TK: Molecular mechanisms of curcumininduced cytotoxicity: induction of apoptosis through generation of reactive oxygen species, down-regulation of $\mathrm{BCl}-\mathrm{XL}$ and IAP, the release of cytochrome $\mathrm{c}$ and inhibition of Akt. Carcinogenesis 2003, 24:1199-1208.

46. Qanungo S, Das M, Haldar S, Basu A: Epigallocatechin-3-gallate induces mitochondrial membrane depolarization and caspase-dependent apoptosis in pancreatic cancer cells. Carcinogenesis 2005, 26:958-967.

47. Park C, Jin CY, Kim GY, Choi IW, Kwon TK, Choi BT, Lee SJ, Lee WH, Choi YH: Induction of apoptosis by esculetin in human leukemia U937 cells through activation of JNK and ERK. Toxicol Appl Pharmacol 2008, 227:219-228. 
48. Tsuiki H, Tnani M, Okamoto I, Kenyon LC, Emlet DR, Holgado-Madruga M, Lanham IS, Joynes CJ, Vo KT, Wong AJ: Constitutively active forms of cJun $\mathrm{NH} 2$-terminal kinase are expressed in primary glial tumors. Cancer Res 2003, 63:250-255.

49. Tournier C, Hess P, Yang DD, Xu J, Turner TK, Nimnual A, Bar-Sagi D, Jones SN, Flavell RA, Davis RJ: Requirement of JNK for stress-induced activation of the cytochrome c-mediated death pathway. Science 2000, 288:870-874.

50. Antonyak MA, Moscatello DK, Wong AJ: Constitutive activation of c-Jun Nterminal kinase by a mutant epidermal growth factor receptor. J Biol Chem 1998, 273:2817-2822.

51. Neumann-Haefelin E, Qi W, Finkbeiner E, Walz G, Baumeister R, Hertweck M: SHC-1/p52Shc targets the insulin/IGF-1 and JNK signaling pathways to modulate life span and stress response in C. elegans. Genes Dev 2008, 22:2721-2735.

52. Kasper B, Brandt E, Ernst M, Petersen F: Neutrophil adhesion to endothelial cells induced by platelet factor 4 requires sequential activation of Ras, Syk, and JNK MAP kinases. Blood 2006, 107:1768-1775.

doi:10.1186/bcr2475

Cite this article as: Liu et al: ABL-N-induced apoptosis in human breast cancer cells is partially mediated by c-Jun $\mathrm{NH}_{2}$-terminal kinase activation. Breast Cancer Research 2010 12:R9.

\section{Submit your next manuscript to BioMed Central and take full advantage of:}

- Convenient online submission

- Thorough peer review

- No space constraints or color figure charges

- Immediate publication on acceptance

- Inclusion in PubMed, CAS, Scopus and Google Scholar

- Research which is freely available for redistribution

Submit your manuscript at www.biomedcentral.com/submit 